\title{
Brine shrimp toxicity of some plants used as traditional medicines in Kagera Region, north western Tanzania
}

\author{
M.J.MOSHI ${ }^{*}$, E. INNOCENT ${ }^{1}$, J.J. MAGADULA ${ }^{1}$, D.F. OTIENO2 ${ }^{2}$, A. WEISHEIT', \\ P.K. MBABAZI ${ }^{3}$ and R.S.O.NONDO ${ }^{1}$ \\ ${ }^{1}$ Department of Biological and Preclinical Studies, Institute of Traditional Medicine, Muhimbili University of \\ Health and Allied Sciences, Box 65001, Dar es Salaam, Tanzania \\ ${ }^{2}$ Department of Biological Sciences, Moi University, Eldoret, Kenya \\ ${ }^{3}$ Faculty of Development Studies, Mbarara University of Science \& Technology, Mbarara, Uganda
}

\begin{abstract}
Dichloromethane and/or ethanol extracts of 30 plants used as traditional medicines in Bukoba district, northwestern Tanzania were evaluated for brine shrimp toxicity. Among the 50 extracts tested, 32 extracts (64\%) showed very low toxicity with $\mathrm{LC}_{50}$ values above $100 \mu \mathrm{g} / \mathrm{ml}$. Among these $12(24 \%)$ which had LC $50>500 \mu \mathrm{g} / \mathrm{ml}$ can be categorized as being practically non-toxic. Among the remaining extracts $19(38 \%)$ which showed $L_{50}>100<500 \mu \mathrm{g} / \mathrm{ml}$ are also considered to be nontoxic. Extracts that showed LC 50 results between $30-100 \mu \mathrm{g} / \mathrm{ml}$ have been categorized as mildly toxic; these include ethanol extracts of Lantana trifolia ( $\mathrm{LC}_{50} 32.3 \mu \mathrm{g} / \mathrm{ml}$ ), Vernonia bradycalyx (LC $\mathrm{L}_{50} 33.9$ $\mu \mathrm{g} / \mathrm{ml}$ ), Antiaris toxicaria (LC50 $38.2 \mu \mathrm{g} / \mathrm{ml}$ ) and Rubus rigidus (LC50 $41.7 \mu \mathrm{g} / \mathrm{ml}$ ) and the dichloromethane extracts of Gynura scandens (LC50 $36.5 \mu \mathrm{g} / \mathrm{ml}$ ) and Bridelia micrantha (LC50 $32.0 \mu \mathrm{g}$ $/ \mathrm{ml}$ ). The dichloromethane extracts of Picralima nitida (LC $\mathrm{LC}_{50} 18.3 \mu \mathrm{g} / \mathrm{ml}$ ) and Rubus rigidus (LC $\mathrm{LC}_{50} 19.8 \mu \mathrm{g}$ $/ \mathrm{ml}$ ), were only moderately toxic. Picralima nitida and Rubus rigidus extracts are only 1.1 and 1.2 less toxic than the standard drug, cyclophosphamide ( $\left.\mathrm{LC}_{50} 16.3 \mu \mathrm{g} / \mathrm{ml}\right)$. In conclusion, the results indicate that among the 30 plants used as traditional medicines, 28 are safe for short term use. Picralima nitida and Rubus rigidus extracts are mildly toxic, but by comparison have a remote possibility to yield active anticancer compounds.
\end{abstract}

Keywords: Traditional medicine; Brine shrimp toxicity; safety evaluation

\section{Introduction}

Traditional medicines support well over $60 \%$ of the rural Tanzanian population (Kisangau et al., 2007). Available evidence suggests that even in urban areas which are well served by modern healthcare facilities a good number of patients rely on traditional healers to meet some of their healthcare needs (Kilima et al., 2003). The Kagera region of northwestern Tanzania is one of places where traditional medicines are widely used and thus play a significant role in the provision of health care. According to Medicine du Monde, a French non-governmental organization in Kagera Region, five out of every six HIV patients receive their medical attention from a traditional healer rather than from a hospital or primary health care facility (Anonymous, 1996). Due to good rains and vegetation cover in the region, there is a rich diversity of medicinal plants present. However most of these are yet to be documented and evaluated for safety and efficacy.

Current efforts therefore aim at documenting these plants and in addition evaluate them for safety and efficacy. Two recent studies in Bukoba rural district (Kisangau et al., 2007; Moshi et al., 2009) have set the pace and more studies are ongoing. This study reports on brine shrimp toxicity tests of extracts from some of the plants reported from Bugabo Ward in Kagera region by Moshi et al. (2009). These tests are normally conducted so as to

\footnotetext{
* Correspondence: Prof. Mainen J. Moshi; E-mail: mmoshi@muhas.ac.tz
} 
draw some inferences on the safety of plant extracts, and to depict trends of their biological activities (Harwig \& Scott, 1971; Meyer et al., 1982).

\section{Materials and Methods}

\section{Materials}

Ethanol was bought from Fisher Scientific UK Ltd. (Loughborough, Leicestershire, UK), Dimethyl sulphoxide (DMSO) from Sigma (Poole, Dorset, UK and Brine shrimp eggs from O.S.I. Marine Lab. Inc., Hayward, CA 94545, USA.. Sea salt was prepared by evaporating water collected from the Indian Ocean along the Dar es Salaam coast.

The plants used in this study are among plants recently reported as being used in traditional medicine in Bukoba rural district (Moshi et al., 2009). The material for this study was collected from Bukoba district in November, 2008 by Mr. Didas Ngemera, a traditional healer participating in the study. The collected material was dried in shade until completely dry and then transported to the Institute of Traditional Medicine in Dar es Salaam where it was ground into powder using a milling machine.

\section{Preparation of extracts brine shrimp lethality test}

Powdered plant material was soaked sequentially in dichloromethane (99\%) and then ethanol (96\%), each for $48 \mathrm{~h}$. However, extracts were obtained from some of the plants using ethanol only. The extracts were filtered and solvents removed using a rotary evaporator at a temperature of $40^{\circ} \mathrm{C}$. The extracts were further dried in a freeze dryer to remove any residual water and then stored in a freezer at $-20^{\circ} \mathrm{C}$ until the day of use.

Solutions of the extracts were made in DMSO, at varying concentrations, and incubated in duplicate vials with the brine shrimp larvae in a total volume of $5 \mathrm{ml}$. Ten brine shrimp larvae were then placed in each of the duplicate vials. Others were placed in a mixture of DMSO $(30 \mu \mathrm{l})$ and seawater to serve as a negative control. Cyclophosphamide, an anticancer drug, was used as a positive control. After $24 \mathrm{~h}$ the nauplii were examined against a lighted background, with a magnifying glass and the average number of survived larvae was determined. The mean percentage mortality was plotted against the logarithm of concentrations and the concentration killing fifty percent of the larvae (LC50) was determined from the graph.

\section{Data analysis}

The mean results of brine shrimp mortality against the logarithms of concentrations were plotted using the Fig P computer program (Biosoft Inc, USA), which also gives regression equations. The regression equations were used to calculate $\mathrm{LC}_{16}, \mathrm{LC}_{50}$ and $\mathrm{LC}_{84}$ values. Confidence intervals (95\% CI) were calculated according to a previously reported method (Litchfield and Wilcoxon, 1949).

\section{Results}

The yield of extracts from plants used ranged between $1.04-4.02 \%$. Of the fifty (50) plant extracts tested, 8 showed little to no toxicity to brine shrimps (Table 1). These included the dichloromethane extracts of Antiaris toxicaria, Asystasia gangetica, and Bersama abyssinica and the ethanol extracts of Anthocleista grandiflora, Canna indica, Gynura scandens and Oxalis latifolia which had LC 50 values above $1000 \mu \mathrm{g} / \mathrm{ml}$. Dichloromethane extracts of Cratispermum 
schweinfurthii and Lantana trifolia and the ethanol extracts of Blumea auriculata and Pseudospondius microcarpa were also practically non-toxic to brine shrimps with LC 50 values of between 500 and $800 \mu \mathrm{g} / \mathrm{ml}$. Dichloromethane extracts of eight plants and ethanol extracts of twelve plants gave $\mathrm{LC}_{50}$ values between 100 and $500 \mu \mathrm{g} / \mathrm{ml}$ (Table 1). The extracts which have potential for toxicity with $\mathrm{LC}_{50}$ values below $100 \mu \mathrm{g} / \mathrm{ml}$ can be categorized into those with LC 50 values of $30-100 \mu \mathrm{g} / \mathrm{ml}$ and those whose LC 50 values were below $30 \mu \mathrm{g} / \mathrm{ml}$. In the former category are dichloromethane extracts of Blumea auriculata, Boerhavia diffusa, Clausena anisata, Teclea nobilis and Vernonia bradycalyx, and ethanol extracts of Clausena anisata, Garcinia buchanannii, Hibiscus cannabinus, Hugonia castenifolia, Lantana trifolia, Vernonia bradycalyx, Antiaris toxicaria, Bidens shimperi and Bridelia micrantha, ethanol extract of Rubus rigidus and dichloromethane extract of Gynura scanden. In the second category are dichloromethane extracts of Picralima nitida (LC50 $18.3 \mu \mathrm{g} / \mathrm{ml}$ ) and Rubus rigidus (LC50 19.8 $\mu \mathrm{g} / \mathrm{ml}$ ) which were almost as toxic as cyclophosphamide (LC50 $16.3 \mu \mathrm{g} / \mathrm{ml}$ ).

Table 1: Brine shrimp toxicity of plant extracts

\begin{tabular}{|c|c|c|c|c|c|}
\hline \multirow[t]{2}{*}{ Botanical name } & \multirow{2}{*}{$\begin{array}{l}\text { Part } \\
\text { tested }\end{array}$} & \multicolumn{4}{|c|}{$\mathrm{LC}_{50}(95 \% \mathrm{CI}) \mu \mathrm{g} / \mathrm{ml}$} \\
\hline & & Dichloromethane & $\frac{\text { LC }_{50} \text { DCMex }}{\text { LC }_{50} \text { CPMD }}$ & Ethanol & $\frac{\text { LC }_{50} \text { EToHex }}{\text { LC }_{50} \text { CPMD }}$ \\
\hline Acanthus puberscens & $\mathrm{L}$ & $133.5(80.9-220.3)$ & 8.2 & $286.4(207.5-395.2)$ & 17.6 \\
\hline Anthocleista grandiflora & SB & 355.6(192.2-657.9) & 21.8 & $>1000$ & $>61.3$ \\
\hline Antiaris toxicaria & WP & $>1000$ & $>61.3$ & $38.2(27.9-52.2)$ & 2.3 \\
\hline Asystasia gangetica & $\mathrm{L}$ & $>1000$ & $>61.3$ & $306.8(189.4-497.0)$ & 18.8 \\
\hline Bersama abyssinica & SB & $>1000$ & $>61.3$ & 127.7(95.9-164.7) & 7.8 \\
\hline Bidens shimperi & $\mathrm{L}$ & - & - & $46.9(25.5-86.3)$ & 2.9 \\
\hline Blumea auriculata & $\mathrm{L}$ & $57.7(38.2-87.1)$ & 3.5 & $682.0(296.5-1568.6)$ & 41.8 \\
\hline Boerhavia diffusa & $\mathrm{AP}$ & $71.5(45.5-112.2)$ & 4.4 & $232.4(139.2-388.1)$ & 14.2 \\
\hline Bridelia micrantha & $\mathrm{R}$ & 298.0(181.7-488.7) & 18.3 & $32.0(20.3-50.3)$ & 2.0 \\
\hline Canna indica & $\mathrm{L}$ & $273.9(167.8-447.0)$ & 16.8 & $>1000$ & $>61.3$ \\
\hline Clausena anisata & $\mathrm{R}$ & $71.9(49.6-104.2)$ & 4.4 & $60.5(43.3-84.5)$ & \\
\hline Crassocephallum vitellinum & $\mathrm{R}$ & - & - & $>1000$ & $>61.3$ \\
\hline Craterispermum schweinfurthii & $\mathrm{AP}$ & $513.0(278.8-943.9)$ & 31.5 & - & - \\
\hline Ficus asperifolia & SB & $332.4(211.2-523.2)$ & 20.4 & $250.4(145.7-430.40$ & 15.4 \\
\hline Ficus exasperate & $\mathrm{L}$ & - & - & $126.9(96.1-167.5)$ & 7.8 \\
\hline Garcinia buchananii & $\mathrm{L}$ & $207.0(122.5-349.8$ & 12.7 & $60.6(45.6-80.6)$ & 3.7 \\
\hline Gynura scandens & $\mathrm{L}$ & $36.5(15.3-85.8)$ & 2.2 & $>1000$ & $>61.3$ \\
\hline Hibiscus cannabinus & $\mathrm{AP}$ & - & - & $97.8(73.0-131.0)$ & 6.0 \\
\hline Hugonia castenifolia & $\mathrm{L}$ & 217.1(109.6-429.8) & 13.3 & $66.7(50.9-87.4)$ & 4.1 \\
\hline Jasminum dichotumum & $\mathrm{L}$ & - & - & 190.7(157.6-230.7) & 11.7 \\
\hline Lantana trifolia & $\mathrm{AP}$ & $756.0(315.0-1014.4)$ & 46.4 & $32.3(20.2-51.7)$ & 2.0 \\
\hline Maesopsis eminnii & $\mathrm{L}$ & $133.4(83.9-212.1)$ & 8.2 & $218.1(138.9-342.4)$ & 13.4 \\
\hline Oxalis latifolia & $\mathrm{L}$ & - & - & $>1000$ & $>61.3$ \\
\hline Picralima nitida & SB & $18.3(11.9-28.2)$ & 1.1 & 104.4(73.5-148.2) & 6.4 \\
\hline Plumbago zeylanica & $\mathrm{L}$ & - & - & 232.3(177.3-304.3) & 14.2 \\
\hline Pseudospondius microcarpa & $\mathrm{L}$ & - & - & $541.2(300.7-974.2)$ & 33.2 \\
\hline Rubus rigidus & SB & $19.8(11.4-34.4)$ & 1.2 & $41.7(30.0-58.0)$ & 2.5 \\
\hline Teclea nobilis & $\mathrm{AP}$ & $75.5(56.8-100.4)$ & 4.6 & $156.6(101.7-241.2)$ & 9.6 \\
\hline Vangueria infausta & $\mathrm{L}$ & - & - & $144.7(115.8-180.9)$ & 8.9 \\
\hline Vernonia bradycalyx & $\mathrm{L}$ & $90.8(61.3-134.4)$ & 5.6 & $33.9(24.2-47.5)$ & 2.1 \\
\hline Cyclophosphamide & - & \multicolumn{4}{|c|}{$16.3(10.6-25.2)$ Data from Moshi et al, 2004.} \\
\hline
\end{tabular}

Key: - = not done; $\mathrm{L}=$ leaves; $\mathrm{AP}=$ aerial parts; $\mathrm{SB}=$ stem bark; $\mathrm{R}=$ roots; $\mathrm{WP}=$ whole plant; $\mathrm{DCMex}=$ dichloromethane extract, $\mathrm{EToHex}=$ ethanol extract, $\mathrm{CPMD}=\mathrm{Cyclophosphamide}$ 


\section{Discussion}

The brine shrimp results in this study are interpreted as follows: $\mathrm{LC}_{50}<1.0 \mu \mathrm{g} / \mathrm{ml}-$ highly toxic; $\mathrm{LC}_{50} 1.0-10.0 \mu \mathrm{g} / \mathrm{ml}$ - toxic; $\mathrm{LC}_{50} 10.0-30.0 \mu \mathrm{g} / \mathrm{ml}$ - moderately toxic; $\mathrm{LC}_{50}>30<100$ $\mu \mathrm{g} / \mathrm{ml}-$ mildly toxic, and $>100 \mu \mathrm{g} / \mathrm{ml}$ as non-toxic. Cyclophosphamide (LC $5016.3 \mu \mathrm{g} / \mathrm{ml}$ ) was used as a standard so that it can allow some inference to be made for potential to yield anticancer compounds.

The brine shrimp test results indicate that $64 \%$ of the plant extracts tested had $\mathrm{LC}_{50}$ values above $100 \mu \mathrm{g} / \mathrm{ml}$ which suggests that they are practically non-toxic. As traditional medicines, most of the extracts are prepared as decoctions, which, in a way is mirrored on the ethanol extracts, the results of which suggest that the way they are used poses no threat of acute toxicity. Some of the extracts, including Antiaris toxicaria ( LC50 $38.2 \mu \mathrm{g} / \mathrm{ml}$ ), Bidens shimperi (LC50 $46.9 \mu \mathrm{g} / \mathrm{ml}$ ), Bridelia micrantha (LC50 $32.0 \mu \mathrm{g} / \mathrm{ml}$ ), Lantana trifolia (LC50 32.3 $\mu \mathrm{g} / \mathrm{ml}$ ), Rubus rigidus (LC50 $41.7 \mu \mathrm{g} / \mathrm{ml}$ ) and Vernonia bradycalyx (LC50 $33.9 \mu \mathrm{g} / \mathrm{ml}$ ), are mildly toxic and probably have no obvious danger of outright toxicity during acute exposure.

Dichloromethane extracts for Picralima nitida (LC $\mathrm{L}_{50} 18.3 \mu \mathrm{g} / \mathrm{ml}$ ) and Rubus rigidus (LC50 $19.8 \mu \mathrm{g} / \mathrm{ml}$ ) were the most toxic. However extracts from these two plants used as traditional medicines are unlikely to have any ill effects on patients as they are not on the highly toxic category.

Some brine shrimp results that are already available (Moshi et al., 2006; 2004) provide a circumstantial evidence that plant extracts with $\mathrm{LC}_{50}$ values below $20 \mu \mathrm{g} / \mathrm{ml}$ have a likelihood of yielding anticancer compounds. This corroboration is demonstrated by Bridelia cathartica (Moshi et al., 2004; Suffness et al., 1988), Croton macrostachys (Moshi et al., 2004; Kupchan et al., 1969), Maytenus putterlickioides (Moshi et al., 2004; Shibuta, 1984), Ozoroa insignis (Moshi et al., 2004; Abreu et al., 1999), Psorospermum febrifugum (Moshi et al., 2006; Abou-Shoer et al., 1988; Kupchan et al., 1980), Phyllanthus engleri (Moshi et al., 2006; Ratnayake et al., 2009) and Ximenia americana (Moshi et al., 2004; Asres et al., 2001. This cutoff point has also been suggested elsewhere (Geran et al., 1972). In the 2004 study using brine shrimps, Phyllanthus engleri gave an $\mathrm{LC}_{50}$ of $0.47 \mu \mathrm{g} / \mathrm{ml}$ (Moshi et al., 2004), and recently the plant yielded englerin A, a selective anti-cancer compound against kidney cancer cells (Ratnayake et al., 2009), which provides further corroborative evidence on the potential of the brine shrimp test to predict the presence of anti-cancer compounds in plant extracts. It is therefore possible that in this study, dichloromethane extracts of Picralima nitida (LC50 18.3 $\mu \mathrm{g} / \mathrm{ml}$ ) and Rubus rigidus ( $\mathrm{LC}_{50} 19.8 \mu \mathrm{g} / \mathrm{ml}$ ) may have potential to yield compounds active against cancer cell lines, and is consistent with the results of cyclophosphamide (LC Fo $_{16.3}$ $\mu \mathrm{g} / \mathrm{ml}$ ) and the criterion set by Geran et al. (1972. As compared to cyclophosphamide the two LC50 values are only 1.1 and 1.2 times higher, and probably not too far fetched to speculate of their possibility to yield cancer cell line active compounds.

In conclusion most of the extracts of the plants tested seem to be innocuous on short term use. Dichloromethane extracts of Picralima nitida and Rubus rigidus which were the most toxic among the tested extracts have $\mathrm{LC}_{50}$ values that suggest a remote possibility that they may yield cancer cell line active compounds.

\section{Acknowledgements}

This work would not have been possible without the co-operation of Mr. Didas Ngemera and his family together with their village members who accepted to give us information on 
their medicinal plants. We thank the NAPRALERT Data base of the University of Illinois at Chicago for allowing us access and literature retrieval. We also thank Mr. Selemani Haji for identifying the plants; Mr. Superatus Chuma and Mr. Daniel Kamala for their contribution to this work. This collaborative Lake Victoria Research (VicRes) was financially supported by SIDA-SAREC through the Inter-University Council of East Africa. The project is VicRes Project No. 31 (see (http://www.vicres.net).

Received 27 October 2009

Revised 30 November 2009

Accepted 3 December 2009

\section{References}

Abou-Shoer, M., Boettner, F.E., Chang, C. \& Cassady, J.M. (1988) Antitumour and cytotoxic xanthones of Psorospermum febrifugum. Phytochemistry 27, 2795-2800.

Abreu, P.M., Martins, E.S., Kyser, O., Bindseil, K.U., Siems, K., Seemann, A. \& Frevert, J. (1999) Antimicrobial antitumour and antileischmania screening of medicinal plants from Guinea-Bissau. Phytomedicine 6, 187-195.

Anonymous (1996) Traditional healers learn they have a role to play in Tanzania's AIDScontrol programme. AIDS Analysis Africa 6, 12-13.

Asres, K., Bucar, F., Kartinig, T., Witvrouw, M., Pannecoupue, C. \& De Clercq, E. (2001) Antiviral activity against humanimmunodeficiency virus type 1 (HIV-1) and type 2 (HIV-2) of ethnobotanically selected Ethiopian medicinal plants. Phytotherapy Research 15, 62-69.

Geran, R.I., Greenberg, N.H., McDonald, M.M. \& Abbott, B.J. (1972) Protocols for screening chemical agents and natural products against animal tumors and other biological systems. Cancer Chemotherapy Reports, Part 33, 1-17.

Hartl, M. \& Humpf, H. U. (2000) Toxicity assessment of fumonisins using the brine shrimp (Artemia salina) bioassay. Food and Chemical Toxicology 38, 1097-1102.

Harwig, J. \& Scott, P. (1971) Brine shrimp (Artemia salina L.) larvae as a screening system for fungal toxins. Applied Microbiology 21, 1011-1016.

Kilima, P.M., Ostermayer, I., Shija, M., Wolff, M.M. \& Evans, P.J. (1993) Drug utilization, prescribing habits and patients in City Council Health Facilities, Dar es Salaam, Tanzania. DUHP, Swiss Tropical Institute, Basel, p. 19.

Kisangau, D.P., Lyaruu, H.V., Hosea, K.M. \& Joseph, C.C. (2007) Use of traditional medicines in the management of HIV/AIDS opportunistic infections in Tanzania: a case in the Bukoba rural district. Journal of Ethnobiology and Ethnomedicine 3,29

Kupchan, S.M., Hemingway, R.J. \& Smith, R.M. (1969) Tumor inhibitors. XLV. Crotepoxide, a novel cyclohexane diepoxide tumor inhibitor from Croton macrostachys. Journal of Organic Chemistry 34, 3898-3902.

Kupchan, S.M, Streelman, D.R. \& Sneden, A.T. (1980) Psorospermin, a new antileukemic xanthone from Psorospermum febrifugum. Journal of Natural Products 43, 296-301.

Litchfield, J.R. Jr. \& Wilcoxon, F. (1949) A simplified method of evaluating dose-effect experiments. Journal Pharmacology and Experimental Therapeutics 96, 99-113.

Meyer, B.N., Ferrigini, R.N., Putnam, J.E., Jacobsen, L.B., Nichols, D.E., McLaughlin, J.L. (1982) Brine shrimp: A convenient general bioassay for active plant constituents. Planta Medica 45, 31-35. 
Moshi, M.J., Cosam, J.C., Mbwambo, Z.H., Kapingu, M. \& Nkunya, M.H.H. (2004) Testing Beyond Ethnomedical Claims: Brine Shrimp Lethality of Some Tanzanian Plants. Pharmaceutical Biology 42, 547-551

Moshi, M.J., Mbwambo, Z.H., Nondo, R.S.O., Masimba, P.J., Kamuhabwa, A., Kapingu, M.C., Thomas, P. \& Richard, M. (2006) Evaluation of ethnomedical claims and brine shrimp toxicity of some plants used in Tanzania as traditional medicines. African Journal of Traditional, Complementary and Alternative Medicines 3, 48 - 58

Moshi, M.J., Otieno, D.F., Mbabazi, P.K. \& Weisheit, A. (2009) The Ethnomedicine of the Haya people of Bugabo ward, Kagera Region, north western Tanzania. Journal of Ethnobiology and Ethnomedicine 31, 5:24.

Ratnayake, R., Covell, D., Ransom, T.T., Gustafson, K.R. \& Beutler, J.A. (2009) Englerin A,. A selective inhibitor of renal cancer cell growth, from Phyllanthus engleri. Organic Letters 11, 57-60.

Shibuta, Y. (1984) Supercritical fluid extraction and examination of its applicability to crude materials for medicines from plant sources. Abstracts of the 5th Symposium on Development and Application of Naturally Occurring Drug Materials. pp. 29-34.

Suffness, M., Abbott, B., Statz, D.N., Wonilowicz, E. \& Spjut, R (1988) The utility of P388 leukaemia compared to B16 melanoma and colon carcinoma 38 for in vivo screening of plant extracts. Phytotherapy Research 2, 89-97. 